\title{
Kualitas Fisik dan Kimia Sungai Citarum yang bermuara ke Waduk Cirata di Wilayah Kabupaten Cianjur
}

\author{
Bramantiyo Eko Putro', Isma Masrofah ${ }^{2}$ \\ 1,2Teknik Industri, Fakultas Teknik, Universitas Suryakancana, Cianjur \\ Correspondence email: bramantiyo@unsur.ac.id
}

\begin{abstract}
Abstrak. Pencemaran Daerah Aliran Sungai (DAS) Citarum mendapatkan perhatian khusus dari pemerintah untuk dilakukan penanggulangan secara cepat. Penanggulangan pencemaran harus dilakukan di bagian hulu, tengah dan hilir. Salah satu DAS Citarum yang berada pada bagian tengah yaitu waduk Cirata. Pencemaran di waduk Cirata tidak hanya berasal dari lingkungan waduk, tetapi juga dari aliran-aliran sungai yang bermuara ke waduk Cirata. Waduk Cirata selain sebagai unit Pembangkit Listrik Tenaga Air (PLTA), waduk ini pun dimanfaatkan oleh masyarakat untuk budidaya ikan dalam teknik Kolam Jaring Terapung (KJA). Penelitian ini bertujuan untuk mengetahui zat pencemar yang paling dominan mencemari waduk Cirata. Uji kualitas air sungai dan waduk dilakukan dengan bantuan uji lab oleh Labkesda. Perolehan data penelitian dilakukan dengan mendapatkan data pengujian kualitas air bersih dari beberapa 3 titik muara aliran sungai menuju waduk Cirata dan 4 titik sentra waduk Cirata sejumlah 40 sampel. Teknik pengolahan data dilakukan menggunakan data mining yaitu Exploratory Data Analysis. Hasil uji parameter lab yang diperbandingkan dengan standar Permenkes No 32 Tahun 2017 menunjukkan bahwa mayoritas parameter kualitas fisik dan kimia sungai Citarum yang bermuara ke Waduk Cirata masih dalam ambang batas yang diprasyaratkan. Sebagian besar sampel air sungai dan waduk memiliki kualitas air yang memenuhi syarat sebagai air bersih. Sebanyak 5 sampel $(12,5 \%)$ pada parameter kekeruhan dan 1 sampel $(2,5 \%)$ pada sampel warna tidak memenuhi syarat sebagai air bersih. Hal tersebut dimungkinkan karena pengambilan sampel yang terlalu dekat dengan daratan. Parameter suhu sebanyak 20 sampel (50 \%) tidak memenuhi syarat sebagai air bersih dimungkinkan karena jeda waktu pengambilan sampel. Hasil analisis menunjukkan bahwa jarak sumber pencemar, jumlah sumber pencemar, dan kondisi lingkungan di sekitar pengambilan sampel secara signifikan dengan kadar suhu, TDS, kekeruhan, warna, $\mathrm{pH}$, nitrogen, besi, kesadahan, mangan, fluorida, dan sianida.
\end{abstract}

Kata kunci: DAS Citarum; Exploratory Data Analysis; Pencemaran Cirata; Kualitas air.

Abstract. Pollution prevention must be carried out in the upstream, middle and downstream parts. One of the Citarum watersheds located in the middle part is the Cirata reservoir. Pollution in the Cirata reservoir does not only originate from the reservoir environment, but also from rivers that flow into the Cirata reservoir. Cirata Reservoir besides being a Hydroelectric Power Plant (PLTA) unit, this reservoir is also used by the community for fish farming in the Floating Net Pool (KJA) technique. This study aims to determine the most dominant pollutants contaminating the Cirata reservoir. Test of river and reservoir water quality is carried out with the help of lab tests by Labkesda. The research data was obtained by obtaining clean water quality test data from several 3 estuary points of the river flow to the Cirata reservoir and 4 centers of Cirata reservoir number of 40 samples. Data processing techniques are carried out using data mining, namely Exploratory Data Analysis. The lab parameter test results, which are compared with the Permenkes No. 32 Year 2017 standard, show that the majority of the physical and chemical quality parameters of the Citarum River which empties into the Cirata Reservoir are still within the required threshold. Most river and reservoir water samples have water quality that qualifies as clean water. Five samples (12.5\%) in turbidity parameters and 1 sample (2.5\%) in color samples did not qualify as clean water. This is possible because the sampling is too close to the mainland. Temperature parameters of 20 samples (50\%) do not qualify as clean water is possible because of the lag time of sampling. The results of the analysis showed that the distance of pollutant sources, the amount of pollutant sources, and environmental conditions around the sampling significantly with temperature, TDS, turbidity, color, $\mathrm{pH}$, nitrogen, iron, hardness, manganese, fluoride, and cyanide.

Keywords: Citarum Watershed; Exploratory Data Analysis; Cirata pollution; Water quality

\section{PENDAHULUAN}

Air termasuk kebutuhan paling mendasar bagi manusia karena diperlukan bagi rumah tangga, industri dan pertanian dan meningkatkan derajat kesehatan masyarakat (Boekosono \& Hakim, 2010). Fungsi air tidak dapat digantikan oleh senyawa lain, dengan demikian selayaknya perlu diketahui kandungan di dalamnya (Munfiah, Nurjazuli, \& Setiani, 2013). Ketua Departemen IImu Gizi FKUI-RSCM Fiastuti Witjaksono menyampaikan bahwa manusia membutuhkan senyawa berupa air minimum sebanyak 8 gelas per hari (Rezkisari, 2016). Akan tetapi secara kualitas, air juga merupakan zat yang paling parah akibat pencemaran karena banyak penyakit yang menyerang manusia ditularkan melalui air (Wandrivel, Suharti, \& Lestari, 2012).

Kualitas air dapat diperoleh melalui siklus hidrologi yaitu siklus alamiah yang memungkinkan tersedianya air permukaan dan air laut tetapi pertumbuhan penduduk dan kegiatan manusia menyebabkan kualitasnya sulit diperoleh (Boekosono \& Hakim, 2010). Kualitas air bersih sangat penting dimiliki oleh setiap sumber penampungan air, begitu pula kualitas air waduk juga harus standar kualitas air bersih. Hal ini penting karena penggunaan air tersebut oleh masyarakat, tumbuhan dan hewan yang berada di sekitar waduk. Khususnya bagi waduk Cirata merupakan salah satu waduk di Jawa Barat yang memberikan sekitar $80 \%$ pasokan air untuk wilayah Jakarta. Kualitas air hingga layak minum dan aman bagi kesehatan apabila memenuhi persyaratan secara fisika, mikrobiologi, kimia, dan radioaktif (Wandrivel et al., 2012).

Pengambilan sampel sesuai dengan standardisasi untuk pengujian merupakan salah satu faktor yang menunjang dalam mendapatkan hasil yang memuaskan, misalkan dalam pengambilan sampel kualitas air permukaan dapat dipakai SNI 6989.57-2008. Kualitas air 
dapat dilihat dari beberapa hasil pengujian baik secara fisika, kimia maupun biologi. Pengukuran kualitas air diperlukan untuk memahami karakteristik limbah dan cemaran pada sumber air. Melalui proses pengukuran kualitas air maka akan didapat karakteristik fisika, kimia, dan biologi dari air tersebut.

Seiring dengan pertumbuhan populasi manusia maka hal ini pun akan berbanding terbalik dengan kualitas air permukaan khususnya danau ataupun sungai. Sama halnya dengan pernyataan (Fibriantika, Pawitan, \& Delinom, 2017) bahwa pertumbuhan populasi manusia di DAS Citarum (ditempati sekitar lima belas juta orang pada tahun 2010) akan meningkatkan stress pada lingkungan hidup, yang mana akan meningkatkan pertumbuhan ekonomi dan pembangunan di wilayah tersebut, hal ini yang akan mengancam keberadaan dari DAS Citarum.

Waduk Cirata merupakan waduk yang berada di kawasan tengah DAS Citarum yang termasuk sungai tercemar di dunia dikarenakan limbah domestik yang langsung dibuang ke sungai tanpa pengolahan, menurut (Dharmawan \& Salim, 2017). Adapun beberapa karakteristik air waduk Cirata yaitu memiliki suhu 28 - 29 oC; pH 7 - 9; DO 5 - 9 mg/L (Susanti, Bafadal, Kurnani, Sunardi, \& Henny, 2017), BOD $6 \mathrm{mg} / \mathrm{L}$; COD $17 \mathrm{mg} / \mathrm{L}$ (Fibriantika et al., 2017), Posfor 0,16; Nitrogen > 0,5 $\mathrm{mg} / \mathrm{L} ;(0,02-0,48) \mathrm{mg} / \mathrm{L}$ (Komarawidjaja \& Sukimin, 2005), Mangan $(0,02-0,48) \mathrm{mg} / \mathrm{L} ; \operatorname{Kadmium}(0,002$ $0,012) \mathrm{mg} / \mathrm{L} ; \operatorname{Krom}(0,01-0,06) \mathrm{mg} / \mathrm{L}$; Tembaga $(0,00-$ $0,03) \mathrm{mg} / \mathrm{L}$; Timbal $(0,01-0,03) \mathrm{mg} / \mathrm{L}$; Besi $(1,32-7,11)$ $\mathrm{mg} / \mathrm{L}$ (Sutrisno, Koesoemadinata, \& Taufik, 2016). Jika dihubungkan dengan peraturan pemerintah Nomor 82 Tahun 2001 tentang Pengelolaan Kualitas Air dan Pengendalian Pencemaran Lingkungan, maka kualitas air Waduk Cirata masuk ke dalam kategori kelas II. Kategori kelas II yaitu dimana airnya dapat digunakan untuk prasarana/sarana rekreasi air, pembudidayaan ikan air tawar, peternakan, irigasi dan peruntukan lainnya yang mensyaratkan kegunaan yang sama dengan kegunaan tersebut.

Kegunaan dari waduk Cirata yaitu sebagai Pembangkit Listrik Tenaga Air (PLTA) dan masyarakat sekitar diperbolehkan untuk budidaya air tawar dalam bentuk Keramba Jaring Apung (KJA), adapun jumlah KJA yang diperbolehkan yaitu sebanyak 12.000 petak sebagaimana tercantum dalam Keputusan Gubernur Jabar No. 41 Tahun 2002. Namun, pada kenyataannya jumlah KJA yang berada di Waduk Cirata pada sensus tahun 2018 yaitu sebanyak 98.397 petak. Hal ini akan menjadi tantangan berbagai pihak dalam penertiban KJA, waduk Cirata dapat memproduksi ikan 100 ton per hari, $80 \%$ komoditas perikanan kabupaten Bandung dihasilkan dari waduk Cirata dan Saguling. Oleh karena itu, pemerintah dan satuan terkait perlu mengetahui kualitas fisik dan kimia sungai Citarum yang bermuara ke waduk Cirata.

\section{METODE PENELITIAN}

Penelitian ini merupakan bagian dari penelitian deskriptif dimana dirancang untuk mengumpulkan data yang menggambarkan karakteristik objek (seperti orang, organisasi, produk, atau merek), peristiwa, atau situasi.
Penelitian ini merupakan penelitian kuantitatif dengan menggunakan uji statistik yaitu data mining. Studi pendahuluan dilakukan dengan cara pengambilan sampel awal secara acak untuk menentukan lokasi stasiun berdasarkan jenis aktivitas ada di sungai. Pengambilan sampel pada penelitian ini dilakukan selama 3 bulan. Lokasi pengambilan sampel di tiga titik muara aliran sungai yang menuju waduk Cirata (Citarum, Cisokan, dan Cikundul) dan Waduk Cirata (Jangari, Cipicung, Meleber, dan Palumbon).

Tahap berikutnya dilakukan pengolahan data dengan cara uji lab oleh Laboratorium Kesehtan Daerah (Labkesda) untuk menentukan kualitas air dan zat pencemar yang dominan. Sampel data dibedakan ke dalam kelompok parameter fisik yaitu Suhu, Total Dissolve Solid (TDS), Kekeruhan, Warna. Selain itu terdapat juga kelompok pengukuran parameter kimia yaitu $\mathrm{pH}$, Nitrogen, Besi, Kesadahan, Mangan, Fluorida, dan Sianida. Hasil uji lab dilakukan pengolahan data penelitian menggunakan metode analisis data eksploratori. Hasil analisis parameter fisik dan kimia yang diperoleh disajikan dalam bentuk histogram dengan menggunakan Microsoft Excel 2013. Hasil kemudian dibandingkan berdasarkan baku mutu kualitas air sungai PP No. 82 Tahun 2001 dan Permenkes No. 32 Tahun 2017. Semua hasil pengolahan data dianalisis sehingga menghasilkan informasi yang berguna untuk mencapai tujuan penelitian. Berdasarkan analisa dan pengolahan data, maka dapat diambil kesimpulan dari penelitian yang telah dilakukan.

\section{HASIL DAN PEMBAHASAN}

Pengumpulan data sampel air dilakukan selama 3 bulan hal ini dikarenakan pertimbangan jarak dan akses ke lokasi. Hal tersebut juga agar menghindari diperolehnya sampel yang terlalu mirip satu dengan yang lainnya. Pengambilan sampel air dilakukan di semua titik dalam satu hari yang sama. Setiap pengambilan sampel akan diperoleh tujuh sampel air yang berasal dari Citarum, Cisokan, dan Cikundul, Jangari, Cipicung, Meleber, dan Palumbon. Tujuh sampel yang diperoleh diserahkan ke Labkesda untuk diuji. Hal tersebut dilakukan beberapa kali dalam kurun waktu 3 bulan. Setelah menunggu proses uji lab setiap minggunya, total data yang primer adalah sebanyak 28 sampel dan data sekunder sejumlah 12 sampel.

Data hasil uji lab sampel air pada penelitian ini mencakup parameter fisik kekeruhan, warna, zat padat terlarut, suhu dan parameter kimia $\mathrm{pH}$, besi, fluorida, kesadahan, mangan, nitrat, nitrit, sianida, kromium, sulfat, zat organik. Data yang disajikan dalam pembahasan ini sudah dilakukan penyesuaian dengan cara dikelompokkan. Dari hasil uji lab diperoleh data karakteristik air.

Berdasarkan Tabel 1 dapat disimpulkan bahwa mayoritas sampel yang telah diuji kondisinya baik atau dalam ambang batas yang diprasyaratkan oleh Permenkes No. 32 Tahun 2017. Kondisi baik tersebut utamanya ditunjukkan oleh parameter-parameter kimia yang telah memenuhi standar, sedangkan parameter fisik seperti kekeruhan dan suhu masih terdapat sampel yang dalam kondisi buruk. 
Tabel 1. Kualitas Fisik dan Kimia Air Sungai di Wilayah Kabupaten Cianjur

\begin{tabular}{|c|c|c|c|c|c|c|c|}
\hline No. & Parameter & Rerata \pm SD & Minimum & Maksimum & Median & Baku Mutu & Satuan \\
\hline A & Fisik & & & & & & \\
\hline 1 & Kekeruhan & $11,4 \pm 13,18$ & 2,90 & 58,00 & 6,70 & 25,00 & NTU \\
\hline 2 & Warna & $18,35 \pm 8,55$ & 10,00 & 64,00 & 17,00 & 50,00 & TCU \\
\hline 3 & TDS & $153,88 \pm 35,94$ & 90,00 & 248,53 & 151,21 & 1000,00 & $\mathrm{mg} / \mathrm{l}$ \\
\hline 4 & Suhu & $25,30 \pm 1,37$ & 23,50 & 28,60 & 25,20 & $\pm 3^{\circ} \mathrm{C}$ & ${ }^{\circ} \mathrm{C}$ \\
\hline B & Kimia & & & & & & \\
\hline 5 & $\mathrm{pH}$ & $7,1 \pm 0,40$ & 6,40 & 7,84 & 7,10 & $6,5-8,5$ & $\mathrm{mg} / \mathrm{l}$ \\
\hline 6 & Besi & $0,11 \pm 0,10$ & 0,03 & 0,44 & 0,07 & 1,00 & $\mathrm{mg} / \mathrm{l}$ \\
\hline 7 & Fluorida & $0,17 \pm 0,15$ & 0,10 & 0,71 & 0,10 & 1,50 & $\mathrm{mg} / \mathrm{l}$ \\
\hline 8 & Kesadahan & $75,49 \pm 12,67$ & 50,44 & 100,88 & 73,26 & 500,00 & $\mathrm{mg} / \mathrm{l}$ \\
\hline 9 & Mangan & $0,19 \pm 0,10$ & 0,02 & 0,26 & 0,25 & 0,50 & $\mathrm{mg} / \mathrm{l}$ \\
\hline 10 & Nitrat & $2,04 \pm 2,33$ & 0,16 & 9,65 & 1,14 & 10,00 & $\mathrm{mg} / \mathrm{l}$ \\
\hline 11 & Nitrit & $0,07 \pm 0,06$ & 0,01 & 0,35 & 0,04 & 1,00 & $\mathrm{mg} / \mathrm{l}$ \\
\hline 12 & Sianida & $0,01 \pm 0,007$ & 0,01 & 0,02 & 0,01 & 0,10 & $\mathrm{mg} / \mathrm{l}$ \\
\hline 13 & Kromium & $0,03 \pm 0,01$ & 0,00 & 0,05 & 0,03 & 0,05 & $\mathrm{mg} / \mathrm{l}$ \\
\hline 14 & Sulfat & $23,71 \pm 13,4$ & 9,00 & 71,73 & 17,50 & 400,00 & $\mathrm{mg} / \mathrm{l}$ \\
\hline 15 & Zat Organik & $4,63 \pm 2,03$ & 0,21 & 10,09 & 4,05 & 10,00 & $\mathrm{mg} / \mathrm{l}$ \\
\hline
\end{tabular}

*) Olah data

\section{Kekeruhan}

Kekeruhan mendeskripsikan sifat optik air yang ditentukan berdasarkan banyaknya cahaya yang diserap dan dipancarkan oleh bahan-bahan (bahan organik dan anorganik baik tersuspensi maupun terlarut seperti lumpur, pasir, bahan organik seperti plankton dan mikroorganisme lainnya) yang terdapat dalam air (Irawan \& Sari, 2013). Berdasarkan hasil pengujian 40 sampel didapat nilai kekeruhan berkisar 40,0 - 58,0 NTU yaitu sampel 23, 24, 25, 26, 27. Sampel tersebut terlihat memiliki rentang nilai yang cukup jauh dibandingkan sampel lainnya. Hal ini dimungkinkan waktu pengambilan sampel pada kondisi setelah hujan sehingga mengakibatkan endapan lumpur, pasir dan bahan organik tersuspensi ke dalam air. Oleh karena itu dapat disimpulkan bahwa sampel tersebut merupakan sampel yang nilainya di atas ambang batas yang diprasyaratkan.

\section{Warna}

Warna dapat mengindikasikan keberadaan zat organik, seperti alga atau senyawa humik, warna dapat digunakan sebagai penilaian kuantitatif adanya bahan organik yang berpotensi berbahaya atau beracun dalam air (Shah, 2017). Terlihat dari hasil uji karakteristik 40 sampel nilainya berkisar dari $10-64 \mathrm{TCU}$, sampel 27 memperlihatkan rentang nilai yang cukup jauh dengan sampel lainnya yaitu sebesar 64 TCU, hal ini dimungkin pada pengambilan sampel yang terlalu dekat ke daratan sehingga kandungan humik yang ada di tanah mempengaruhi warna sampel air tersebut. Berdasarkan hasil olah data dapat disimpulkan bahwa hampir keseluruhan sampel berada pada ambang batas yang diprasyaratkan kecuali sampel 27.

\section{TDS}

TDS atau jumlah padatan terlarut merupakan jumlah dari padatan organik maupun anorganik, mineral batuan maupun garam. Dari keseluruhan sampel, sampel 27 memiliki TDS paling rendah yaitu $90 \mathrm{mg} / \mathrm{l}$ sedangkan sampel 35 memiliki nilai TDS yang paling tinggi yaitu $248,53 \mathrm{mg} / \mathrm{l}$, hal ini dimungkinkan pada sampel 35 jumlah mineral batuan lebih tinggi dibandingkan sampel lainnya. Akan tetapi hasil tersebut tetap menunjukkan bahwa keseluruhan sampel masih berada dalam ambang batas yang diprasyaratkan.

\section{Suhu}

Suhu keseluruhan sampel berkisar $24-29^{\circ} \mathrm{C}$, suhu ini dipengaruhi suhu udara sekitar pengambilan sampel, terlebih di perairan dangkal akan lebih terpengaruh dengan pergolakan angin sekitar. Perbedaan suhu sampel ini mungkin dipengaruhi waktu dari pengambilan sampel dan masa penyimpanan sampel, yang memungkinkan terdapat perbedaan suhu udara sekitar pengambilan sampel. Oleh karena itu hasil penelitian menunjukkan bahwa $50 \%$ sampel berada di luar batas ambang yang diprasyaratkan.

\section{$p H$}

$\mathrm{pH}$ keseluruhan sampel berada pada kisaran 6.4 - 7.8 kondisi ini masih mendekati kondisi $\mathrm{pH}$ netral air murni $(\mathrm{pH}=7)$ pada kondisi $25^{\circ} \mathrm{C}$. Sebagian besar perairan alami memiliki pH dalam kisaran 6-9. Perairan di daerah lembap dengan tanah yang sangat terlindi cenderung memiliki $\mathrm{pH}$ lebih rendah daripada perairan di daerah dengan formasi batu kapur atau yang berada di daerah semi-kering atau kering (Boyd, 2015). Dari data yang dihasilkan sampel 30 memiliki $\mathrm{pH}$ paling tinggi yaitu 7.8 kemungkinan terindikasi perairan tersebut dekat dengan daerah formasi batu kapur, sehingga cenderung menuju alkali. Namun hasil tersebut tetap menunjukkan bahwa keseluruhan sampel masih dalam ambang batas yang diprasyaratkan.

\section{Besi}

Kandungan besi untuk keseluruhan sampel berkisar 0,03-0,44 mg/l. Hasil tersebut menunjukkan bahwa keseluruhan sampel penelitian berada pada ambang batas yang diprasyaratkan. Terdapat sampel yang memiliki nilai cukup tinggi yaitu 18, 27, 34, dan 39. Adapun sampel yang memiliki kadar yang lebih tinggi di banding sampel lainnya dimungkinkan berasal dari pengikisan batuan mineral di wilayah perairan, atau sisa limbah rumah tangga yang mengandung besi, atau korosi besi-besi rangka atau drum besi yang dipakai untuk menopang keramba. 


\section{Fluorida}

Kandungan fluorida untuk keseluruhan sampel berkisar antara $0.10-0.71 \mathrm{mg} / \mathrm{l}$, terlihat pada sampel 32, 39 dan 40 cukup signifikan bedanya dengan sampel lain dengan kandungan fluorida sebesar $0.59-0.71$ $\mathrm{mg} / \mathrm{l}$, dimungkinkan fluorida ini berasal dari batuan sekitar perairan. Fluorida dan fluorit merupakan mineral yang paling banyak terdapat dalam batuan dan mineral detrital, yang mana dalam batuan ion flourida ini menggantikan ion $\mathrm{OH}$ yang sama-sama memiliki muatan ion negatif yang setara sehingga dengan mudah membentuk mineral (Triwuri \& Hazimah, 2018). Fluorida yang memiliki kelarutan rendah dalam air, hal ini dimungkinkan kandungan fluorida ini didapat dari endapan yang tersuspensi di air.

\section{Kesadahan}

Kesadahan mewakili konsentrasi ion $\mathrm{Ca} 2+$ dan $\mathrm{Mg2+}$ dan setara dengan konsentrasi senyawa kalsium karbonat (CaCO3). Dari hasil sampel uji kadar kesadahan berkisar 50.4 - $100 \mathrm{mg} / \mathrm{l}$. Menurut F. Joseph \& Jr. Malina dalam (Shah, 2017) hubungan konsentrasi kesadahan dan klasifikasi air alami berdasarkan kandungan $\mathrm{CaCO} 3$ untuk rentang 0 - $60 \mathrm{mg} / \mathrm{l}$ disebut dengan air lunak, 61 - 100 mg/l disebut air cukup sadah, 101 - $180 \mathrm{mg} / \mathrm{l}$ disebut air sadah, > $180 \mathrm{mg} / \mathrm{l}$ disebut air sangat sadah. Berdasarkan kategori ini, hasil pengujian sampel karakteristik air berdasarkan konsentrasi kesadahan yaitu termasuk ke dalam air lunak (sampel 4, 7, 22 dan 27) sedangkan yang lainnya merupakan klasifikasi air yang cukup sadah. Untuk klasifikasi sampel yang cukup sadah ini dimungkinkan kandungan ion-ion kesadahan misalnya perairan dekat dengan daerah mineral batuan yang mengandung kalsium ataupun magnesium. Oleh karena itu dapat disimpulkan bahwa keseluruhan sampel berada dalam ambang batas yang diprasyaratkan.

\section{Mangan}

Mangan merupakan unsur yang cepat bereaksi dalam kondisi asam, mangan diperlukan tubuh sebagai enzim namun kadar yang berlebihan akan mengakibatkan toksin. Kadar mangan pada perairan alami nilainya berkisar $0,2 \mathrm{mg} / \mathrm{l}$, sedangkan pada air tanah dan danau yang dalam kandungannya akan lebih besar, di perairan tawar kadarnya akan berkisar 0,002 $\mathrm{mg} / \mathrm{l}$ atau mungkin bisa lebih dari $4.0 \mathrm{mg} / \mathrm{l}$ (Effendi, 2012). Sampel berasal dari perairan air tawar, menunjukkan kadar mangan berkisar pada $0.02-0.26$ $\mathrm{mg} / \mathrm{l}$. Sampel 1-28 kadarnya lebih tinggi di banding sampel 29 - 40, hal ini dimungkinkan dari kedalaman perairan sekitar sampel. Hasil olah data penelitian ini menunjukkan bahwa keseluruhan sampel masih berada dalam ambang batas yang diprasyaratkan.

\section{Nitrogen}

Nitrogen teroksidasi menjadi senyawa nitrit dan nitrat, karena nitrit mudah teroksidasi menjadi nitrat maka kadar nitrat menjadi lebih tinggi dibanding kadar nitrit. Senyawa nitrat dapat ditemui di perairan alam yang merupakan oksidasi bakteriologis bahan nitrogen dalam tanah. Banyak anion nitrat (NO3) masuk dalam air permukaan bersama dengan air domestik dan air dari industri, pertanian dan Iain-lain. Nitrat adalah salah satu indikator tingkat polusi organik dari zat yang mengandung nitrat (Shah, 2017). Pada sampel 37 kadar nitrit lebih tinggi di banding nitrat hal ini kemungkinan sampel dekat dengan sumber serapan pembuangan tinja dari penduduk setempat, pada sumber serapan kadar oksigen lebih sedikit, sehingga nitrit tidak cepat teroksidasi menjadi nitrat. Berdasarkan hasil tersebut menunjukkan bahwa sampel penelitian ini masih dalam ambang batas yang diprasyaratkan.

Total oksida nitrogen (nitrit dan nitrat) pada sampel 13 - 21, 31, 37 memiliki kadar total oksida nitrogen yang lebih tinggi di banding sampel lainnya hal ini dimungkinkan berasal dari limbah pertanian, limbah dari pakan ternak ikan, dan limbah penduduk yang mana meningkatkan kadar nitrogen dalam air.

\section{Kromium}

Kadar krom pada sampel uji berkisar 0,001 - 0,05 $\mathrm{mg} / \mathrm{l}$. Pada sampel 27 ini dimungkinkan nilainya lebih tinggi dibanding yang lainnya karena pengambilan sampel yang cukup dekat ke daratan. Hal ini dikarenakan nilai krom pada perairan alam berasal dari pelapukan dari batuan dan adanya limpasan tanah dari daratan. Sedangkan pada sampel 33, 38, 39, 40 kandungan krom sangat kecil sekali dibandingkan dengan yang lainnya kemungkinan kandungan mengendap pada sedimen dibandingkan dalam air yang diakibatkan oleh $\mathrm{pH}$ yang lebih alkali, sesuai dengan yang dituliskan dalam (Nuraini, Endrawati, \& Maulana, 2018) bahwa dalam pH alkali sekitar 7,93 - 9,36 akan terjadi senyawa yang lebih kompleks, terjadi perubahan krom dari bentuk karbonat menjadi hidroksida yang sulit terlarut dalam air dan berikatan dengan partikel air yang kemudian mengendap ke dasar perairan. Akan tetapi hasil tersebut masih berada di ambang batas yang diprasyaratkan.

\section{Sulfat}

Kandungan Sulfat pada sampel uji berkisar 9 $71,7 \mathrm{mg} / \mathrm{l}$. Sulfat merupakan bentuk sulfur utama yang terkandung di tanah dan perairan, sulfat yang berikatan dengan hidrogen membentuk asam sulfat dan sulfat yang berikatan dengan logam alkali merupakan bentuk sulfur yang paling banyak ditemukan di danau dan sungai (Hadiarti, 2015). Sampel dengan kadar sulfat paling besar pada sampel 33. Hal ini dimungkinkan keberadaan sulfat dalam bentuk asam sulfat dan karena letaknya berdekatan dengan daratan dimana mengandung logam alkali. Oleh karena itu banyak juga sulfat yang berikatan dengan logam alkali. Sedangkan pada sampel 7 memiliki kadar sulfat paling rendah hal ini dimungkinkan keberadaan sulfat hanya dari bentuk asam sulfat dan memiliki sedikit kandungan logam alkali. Keseluruhan sampel pada penelitian ini berada pada ambang batas yang diprasyaratkan.

\section{Zat Organik}

Kandungan zat organik dari seluruh sampel yang diuji berkisar 0,2 - 10,1 mg/l. Keberadaan zat organik yang berasal dari alam akan mengakibatkan timbulnya bau, rasa dan juga kekeruhan serta warna pada air. Hal ini bisa berasal dari sisa-sisa tumbuhan, peternakan, 
maupun limbah rumah tangga. Pada sampel 15 nilai kandungan zat organiknya paling tinggi dibandingkan yang lainnya kemungkinan disebabkan dari limbah peternakan budidaya ikan $(\mathrm{KJA})$ dan banyaknya tanaman eceng gondok sedangkan pada sampel 23 dan 27 nilai kandungan zat organik lebih kecil dibandingkan sampel yang lainnya, dimungkinkan karena zat organik lebih sedikit karena daerah perairan bukan daerah tempat budidaya ikan (KJA) dan tidak terdapat eceng gondok, kandungan zat organik berasal dari tumbuhan sekitar daratan. Hasil olah data penelitian ini masih menunjukkan bahwa samepl berada di ambang batas yang diprasyaratkan.

\section{SIMPULAN}

Sebagian besar sampel air sungai dan waduk memiliki kualitas air yang memenuhi syarat sebagai air bersih. Sebanyak 5 sampel (12,5\%) pada parameter kekeruhan dan 1 sampel (2,5\%) pada sampel warna tidak memenuhi syarat sebagai air bersih. Hal tersebut dimungkinkan karena pengambilan sampel yang terlalu dekat dengan daratan. Parameter suhu sebanyak 20 sampel $(50 \%)$ tidak memenuhi syarat sebagai air bersih dimungkinkan karena jeda waktu pengambilan sampel. Hasil analisis menunjukkan bahwa jarak sumber pencemar, jumlah sumber pencemar, dan kondisi lingkungan di sekitar pengambilan sampel secara signifikan dengan kadar suhu, TDS, kekeruhan, warna, $\mathrm{pH}$, nitrogen, besi, kesadahan, mangan, fluorida, dan sianida.

\section{Ucapan Terima Kasih}

Para penulis berterima kasih kepada Kementerian Riset, Teknologi, dan Pendidikan Tinggi Republik Indonesia (KEMENRISTEKDIKTI) dan Universitas Suryakancana karena menyediakan dukungan fasilitas dan keuangan di bawah Nomor Hibah Penelitian: 03 / REK / UNSUR / III / 2019 tanggal 20 Maret 2019.

\section{DAFTAR PUSTAKA}

Boekosono, L., \& Hakim, L. (2010). Tingkat Kualitas Bakteriologis Air Bersih Di Desa Sosial Kecamatan Pagi Kabupaten Boalemo. Jurnal Inovasi, Vol. 7(No. 4), Halaman 240-243.

Boyd, C. E. (2015). Water quality: An introduction. Water Quality: $\quad$ An Introduction. https://doi.org/10.1007/978-3-319-17446-4

Dharmawan, I. W. S., \& Salim, A. G. (2017). Bunga Rampai Pengelolaan Lahan dan Air Berkelanjutan dengan Melibatkan Masyarakat. In M. Mulyanto \& W. S. Dharmawan (Eds.), Bunga Rampai Pengelolaan Lahan dan Air Berkelanjutan dengan Melibatkan Masyarakat (2nd ed., pp. 1-148). Bogor: Forda Press.

Effendi, H. (2012). Telaah Kualitas Air Bagi Pengelolaan Sumber Daya dan Lingkungan Perairan. Yogyakarta: Kanisius.

Fibriantika, E., Pawitan, H., \& Delinom, R. (2017). Increasing Human-Environmental Stresses on Citarum Basin in the Past Decades. In $\mathrm{M}$. Maghfiroh, A. Dianto, T. Jasalesmana, I. Melati, O. Samir, \& R. Kurniawan (Eds.), Lake Ecosystem Health and Its Resilience: Diversity and Risks of
Extinction PROCEEDINGS of the 16th World Lake Conference (pp. 23-30). Bali: Research Center for Limnology, Indonesian Institute of Sciences.

Hadiarti, D. (2015). PENENTUAN KADAR SULFAT AIR MINERAL KEMASAN GELAS YANG BEREDAR DI PONTIANAK DENGAN METODE SM. Ed. 21 Th. 2005. In Prosiding SEMIRATA 2015 (pp. 57-63). Pontianak: Universitas Tanjung Pura. Retrieved from

http://jurnal.untan.ac.id/index.php/semirata2015/arti cle/view/14136

Irawan, A., \& Sari, I. (2013). Karakteristik Distribusi Horizontal Parameter Fisika-Kimia Perairan Permukaan Di Pesisir Bagian Timur Balikpapan. Jurnal IImu Perikanan Tropis, 18(2), 21-27.

Komarawidjaja, W., \& Sukimin, S. (2005). Status kualitas air Waduk Cirata dan dampaknya terhadap pertumbuhan ikan budidaya. Jurnal Teknologi, 6, 6 . Retrieved from http://kelair.bppt.go.id/Jt//2005/vol61/03cirata.pdf

Munfiah, S., Nurjazuli, \& Setiani, O. (2013). Kualitas Fisik dan Kimia Air Sumur Gali dan Sumur Bor di Wilayah Kerja Puskesmas Guntur II Kabupaten Demak. Jurnal Kesehatan Lingkungan Indonesia, 12(2),

154-159. https://doi.org/10.14710/jkli.12.2.154

Nuraini, R. A. T., Endrawati, H., \& Maulana, I. R. (2018). Analisis Kandungan Logam Berat Kromium (Cr) Pada Air, Sedimen Dan Kerang Hijau (Perna viridis) Di Perairan Trimulyo Semarang. Jurnal Kelautan Tropis, 20(1), 48. https://doi.org/10.14710/jkt.v20i1.1104

Rezkisari, I. (2016, March 18). Orang Berbadan Gemuk Disarankan Lebih Banyak Minum. Repbulika. Retrieved from https://www.republika.co.id/berita/gaya-hidup/infosehat/16/03/18/047nvi328-orang-berbadan-gemukdisarankan-lebih-banyak-minum

Shah, C. R. (2017). Which Physical , Chemical and Biological Parameters of water determine its quality?

https://doi.org/10.13140/RG.2.2.29178.90569

Susanti, E., Bafadal, N., Kurnani, T. B., Sunardi, \& Henny, C. (2017). TEMPERATURE EFFECTS ON LEAD TROPHIC TRANSFER WITHIN THE PHYTOPLANKTON -ZOOPLANKTON - NILE TILAPIA/COMMON CARP FOOD WEB: A CASE STUDY FROM THE CIRATA RESERVOIR, INDONESIA. In $M$. Maghfiroh, A. Dianto, $T$. Jasalesmana, I. Melati, O. Samir, \& R. Kurniawan (Eds.), Lake Ecosystem Health and Its Resilience: Diversity and Risks of Extinction PROCEEDINGS of the 16th World Lake Conference (pp. 618-623). Bali: Research Center for Limnology, Indonesian Institute of Sciences.

Sutrisno, S., Koesoemadinata, S., \& Taufik, I. (2016). Tingkat Pencemaran Logam Berat Pada Ekosistem Waduk Di Jawa Barat (Saguling, Cirata, Dan Jatiluhur). Jurnal Riset Akuakultur, 2(1), 103. https://doi.org/10.15578/jra.2.1.2007.103-115

Triwuri, N. A., \& Hazimah, -. (2018). Kandungan Fluoride Dalam Air Minum Isi Ulang Di Kota Batam. Jurnal Rekayasa Sistem Industri, 4(1), 1. 
https://doi.org/10.33884/jrsi.v4i1.719

Wandrivel, R., Suharti, N., \& Lestari, Y. (2012). Kualitas Air Minum Yang Diproduksi Depot Air Minum Isi Ulang Di Kecamatan Bungus Padang Berdasarkan Persyaratan Mikrobiologi. Jurnal Kesehatan Andalas, 1(3). 